\title{
Partisan Politics and Dynamics in the U.S. Agriculture Protection
}

\author{
Jong Hee Park and Nathan M. Jensen
}

Agriculture policy is an important, albeit contentious, political economic issue that has been at the center of trade wars, legal disputes, and a stalling of the current World Trade Organization (WTO) trade round. Unlike trade negotiations in non-agricultural industries, advanced agriculture producers such as members of the European Union and the United States are quite reluctant to liberalize their agriculture sectors. In this articlewe explain the dynamics of agricultural protection in the United States by focusing on the role of partisan politics. We argue that major shifts in the size of U.S. farm support benefits have been shaped by partisan battles over the food stamp program ever since this program's inclusion in the 1971 farm bill. While Democratic Congresses try to increase the size of the food stamp program, Republican Congresses try to shrink it. In the case of divided government, these partisan interventions generate a trade-off between changes in the size of the food stamp program and changes in the size of farm support benefits. This tradeoff becomes necessary due to spending constraints and institutional gridlock. We provide empirical evidence in support of this claim from county-level data on farm payments and food stamp benefits and aggregate changes in both programs between 1973 and 2002.

Key Words: partisan politics, agriculture, trade protection, gridlock, U.S. Congress

A gricultural protection has emerged as one of the most important and contentious trade issues across and within countries. In most developed coun-

* Jong Hee Park (parkjonghee@gmail.com) received a Ph.D. from Washington University in St. Louis and has served as an Associate Professor in the Department of Political Science and International Relations in Seoul National University since 2012.

Nathan Jensen (njensen@wustl.edu) is an Associate Professor of International Business at George Washington University's School of Business. He is the author of 30 peer reviewed articles and 2 books on the relationship between business and politics.

Numerous colleagues and friends have provided comments and suggestions on this project. We thank John Balz, John Mark Hansen, Randy Calvert, Matt Gabel, Jeff Grynavisky, David Karol, Soo Yeon Kim, Bill Lowry, Gary Miller, Hong Min Park, Peter Rosendorff, Boris Shor, Alberto Simpser, Steve Smith, Andy Sobel and Dustin Tingley for their comments on the current and earlier versions of the paper. We also appreciate comments from participants of the 2008 Annual Meeting of International Political Economy Society. Yelena McElwain, Michael Salera, and Michael Dickerson helped us collect data. Nathan Jensen acknowledges the financial support of the Weidenbaum Center on the Economy, Government, and Public Policy at Washington University in St. Louis. The usual disclaimer applies. 
tries, legislatures redistribute income from consumers and taxpayers to farmers through tariffs, quotas, and subsidies. These policies are often met with stiff domestic opposition. According to Environmental Working Group, a nongovernmental organization that monitors agriculture and health-related policies, more than 630 news articles calling for reform of farm bills have been published in the United States since 2007 (Environmental Working Group 2013). Agricultural policy is also a central issue in international trade law, where exporting countries have recently challenged the legitimacy of agricultural subsidies to the World Trade Organization's (WTO) dispute settlement mechanism.

Two of the most recent examples are the WTO's ruling against U.S. cotton policy in 2005, and Canada's 2007 protest to the WTO about U.S. support for its corn farmers. Despite these cases, momentum for reform has been slow to develop, and agriculture policy remains the key stumbling block for the current trade agenda. Given this domestic and international opposition, it is highly important to ask what factors allow for the continuation of these trade-distorting programs that economists around the world roundly reject. ${ }^{1}$ In this article, we seek to make a contribution to this area of research by investigating the role of partisan politics in U.S. agriculture policy.

Viewed from economic theories of international trade, e.g., the Ricardian model and the Hecksher-Ohlin model, agricultural protectionism in the UnitedStates is a puzzle. The United States is one of most efficient producers of agricultural products in the world with huge endowment of land. According to the Organization for Economic Cooperation and Development (OECD), the United States had been the largest agricultural exporter in the world until the 1990s. Measured between 2000 and 2004, the United States was the second largest agricultural exporter with an average of $\$ 60.18$ billion in exports (about $18.2 \%$ of world total), following the European Union (EU15) with $\$ 61.78$ billion (18.7\% of total) (OECD 2007). Reflecting its competitive advantage, U.S. governments have been the most active player in liberalizing foreign agricultural markets since the 1970s. ${ }^{2}$

In this articles, we explain dynamics of agricultural protection in the United States by focusing on the role of partisan politics. We argue that unified party control of both houses, which we call unified Congress, is an institutional context that

\footnotetext{
${ }^{1}$ For comparative studies of agriculture protection, see Anderson and Hayami (1986), Gardner (1987), Thies (1998), Gawande and Hoekman (2006), Park and Jensen (2007), Thies and Porche (2007), and Daugbjerg and Swinbank (2012).

${ }^{2}$ For an in-depth investigation on the role of the United States in liberalizing agricultural markets in the EU and Japan, see Davis (2003).
} 
enables majority party leaders to turn farm policy into a mechanism for funneling resources to co-partisan districts. ${ }^{3}$ Bicameral majorities have significant procedural advantages in committees, on the floor and during the process of amendments between two houses. In particular, the control of conference committee by bicameral majority provides an important venue to structure farm bills in favor of majority partisan interests. The extreme reversion point in farm bills, price support programs dating back to 1948, significantly weakens the power of other actors such as presidents and minority party members vis-à-vis the bicameral majority.

Agriculture policy has rarely been considered as a highly partisan issue by scholars of American politics (for example, see Lowi 1964). Legislators from rural districts and senators from farm states are assumed to share common interests in protecting agriculture using government money. The strong committee structure and commodity-specific subcommittees serve as important venues for coordinating legislative activities to protect agricultural interests at the expense of consumers, taxpayers, and foreign producers (Shepsle and Weingast 1987; Krehbiel 1991). ${ }^{4}$ Investigating agriculture policy in the 104th House, Hurwitz, Moiles and Rohde (2001) find that some agricultural issues are highly partisan; but no generalizable argument has been made with regard to the effect of partisan composition of government.

In this article, we argue that the partisan composition of government does have a systematic effect on U.S. agriculture policy. The partisan connection has not been noticed because of one confounding factor: the food stamp program. ${ }^{5}$ The food stamp program was inserted into omnibus farm bills in the early 1970s to facilitate vote trade between nutrition program supporters and farm subsidy sup-

${ }^{3}$ Unified Congress indicates a Congress in which one party holds the majority in both chambers. Note that researchers often use other terms such as bicameral majority or unified Congress to indicate the unified party control of Congress.

${ }^{4}$ Distributive views of congressional organizations exemplify this traditional perspective focusing on institutional foundations of committee power (Shepsle and Weingast 1987). While the informational theory of congressional organizations proposed by Krehbiel (1991) generally opposes the explanation of congressional organizations based on distributive gains, Krehbiel also acknowledges "the pursuit of distributive benefits surely plays a role in agricultural policy-making ... and almost no one disputes that commodity-based subcommittees are organized attempts to facilitate gains from trade" (Krehbiel 1991, 11).

${ }^{5}$ The food stamp program is now known as Supplemental Nutrition Assistance Program (SNAP). SNAP includes a variety of federal food assistance programs such as the National School Lunch Program, the Community Food Project grants, and the Farmers Market Promotion Program. In this article, we indicate the food stamp program to include other nutrition programs. Farm support programs include a variety of agricultural support programs, such as commodity support programs, but exclude nutrition programs, environmental aid, and rural development aid. 
porters. One important consequence of the inclusion of the ever-increasing food stamp program in farm bills, comprising $66 \%$ of the 2002 farm bill spending ( $\$ 178$ billion out of $\$ 270$ billion), is a trade-off in the expansion of farm support programs with that of the food stamp program when Congress cannot increase the total budget of a farm bill. Due to the multiple veto points in the farm bill process, unified party control of government is necessary for both programs to expand simultaneously. In the absence of unified party control of government, however, Congress has to either maintain the status quo or expand one program at the expense of the other.

We test our claim using both aggregate program benefits data and county-level distribution of farm payments and food stamp benefits between 1973 and 2002. From aggregate program benefits data, we found that Democratic Congresses increased the size of the food stamp program at the expense of farm support programs, while Republican Congresses restricted the size of the food stamp program and increased the size of farm support programs. County-level payment data show further evidence of these effects. Finally, a close look at trends from the 1996 farm bill supports our theory and demonstrates the interplay between a bicameral Congress, the president, and trade-offs between farm support and food stamp program benefits.

\section{INSTITUTIONS, FOOD STAMPS, AND U.S. AGRICULTURE POLICY}

U.S. agricultural protection originated in 1938 with the Agricultural Adjustment Act, and subsequent Congresses strengthened the commitment to agricultural protection through the Commodity Credit Corporation Charter Act of 1948 and the Agricultural Act of 1949 (Hansen 1991). Congress has reauthorized these laws roughly every fifth year through multi-year farm bills, which are the key legislative actions that fundamentally shape agricultural protection in the United States. ${ }^{6}$

Between 1973 and 2008, there have been eight omnibus farm bills. Table 1 summarizes the partisan composition of the eight Congresses that authorized these bills. Despite the relatively brief time period of 35 years, there is significant vari-

\footnotetext{
${ }^{6}$ Although Congress can change farm programs in the annual budget reconciliation, farm programs are complex pieces of legislation that consume a large amount of legislators' time and effort. Therefore, opportunities to change the main structure of farm programs are largely limited to the periodic omnibus farm bills. In that sense, the politics surrounding these periodic bills is a microcosm of the broader farm politics of the United States.
} 
ation in congressional partisan composition: five periods of unified party control and three periods of divided control. Four of these unified periods came under Democratic control; one came under Republican control (1996). In one instance, leading up to the 1977 bill, Democrats controlled Congress and the presidency. There has been no farm bill reauthorized by a unified Republican government.7

Table 1. Seven Omnibus Farm Bills and Partisan Control of Congress and Presidency

\begin{tabular}{ccccccccc}
\hline \hline Farm Bill & 1973 & 1977 & 1981 & 1985 & 1990 & 1996 & 2002 & 2008 \\
\hline President & Rep & Dem & Rep & Rep & Rep & Dem & Rep & Rep \\
Senate & Dem & Dem & Rep & Rep & Dem & Rep & Dem & Dem \\
House & Dem & Dem & Dem & Dem & Dem & Rep & Rep & Dem \\
\hline Unified Congress & Yes & Yes & No & No & Yes & Yes & No & Yes \\
Unified Government & No & Yes & No & No & No & No & No & No \\
\hline \hline
\end{tabular}

Note: "Rep" and "Dem" stand for Republican Party control and Democratic Party control in each chamber, respectively.

\section{THE FOOD STAMP-FARM SUBSIDY COALITION}

The legislative origin of the food stamp program is the Food Stamp Act of 1964, in which Congress turned a temporary three-year pilot program into a permanent entitlement program. ${ }^{8}$ In need of reauthorization allies, food stamp program supporters, largely urban Democrats, traded votes with rural Democrats who favored farm support. The common party membership shared by both factions was not enough to maintain unity over time, however, as there was an "increasing sense among the parties to the trade that the other side was not keeping its part of the bargain" (Ferejohn 1986, 237). As an institutional solution to the unstable vote trade, House Agriculture Chairman William Poage added food stamps to the farm bill so that the two sides no longer held each other hostage. This linkage of farm support with food stamps has provided a powerful coalition for both programs.

We highlight one important lingering effect that the inclusion of the food stamp program in farm bills has had on the politics of agricultural policy in the United States. Lumping farm programs with food stamps created a trade-off between changes in the size of the two programs when Congress cannot increase the total size of a farm bill. The trade-off has become more pronounced over time since the

\footnotetext{
${ }^{7}$ Vermont Senator Jim Jeffords switched his party status from Republican to Independent in 2001, caucusing with the Democrats on procedural matters, and thus giving them control of the Senate. While Republicans regained control of the Senate in 2002, in the interim, Congress re-authorized the 2002 farm bill.

${ }^{8}$ Entitlement programs are mandatory programs in which eligible people have legal rights to receive benefits regardless of the budget condition.
} 
size of the food stamp program overtook farm payments as a percentage of the farm bill's total costs in the 1990s. Now, the cost of the food stamp program alone comprises $66 \%$ of the farm bill spending total ( $\$ 178$ billion out of $\$ 270$ billion, 2002-2008) (Chite 2008). In order to curtail the size of the food stamp program, Congress instituted a legal budget constraint on the size of farm bills several times: the Gramm-Rudman-Hollings Balanced Budget and Emergency Deficit Control Act of 1985, the Budget and Emergency Deficit Control Reaffirmation Act of 1987, the Budget Enforcement Act of 1990, and the Balanced Budget Act of 1997. We will show that even in the absence of legal constraint, the partisan composition of Congress and the presidency can serve as an institutional constraint on the growth of the farm bill budget.

\section{PARTISAN COMPOSITION OF GOVERNMENT AND THE TRADE-OFF}

It is straightforward to show, using a simple one-dimensional spatial model, that the simultaneous expansion of both programs would occur only under unified government. Suppose the policymaking process over the size of the farm bill budget as a spatial competition over a unidimensional space, as in Kiewiet and McCubbins (1988) and Krehbiel (1996). The left end of the spectrum indicates the maximum spending on a farm bill and the right end indicates minimum farm bill spending. ${ }^{9}$ In order for the size of the two programs to change in the same direction, all pivotal players should be located either to the left (indicating a preference for the expansion of the two programs) or to the right of the status quo. This could happen only in the unified party control of government. ${ }^{10}$

On the other hand, it is difficult for Congress to change the total size of farm bill spendings in the presence of an opposition president. However, Congress can still make preferred changes in the relative size of the two program spendings by decreasing the size of one program at the expense of the other if one party holds majority positions in both chambers. In other words, bicameral majority in Congress is a necessary condition for significant changes in the size of the two

\footnotetext{
${ }^{9}$ The game proceeds in the same way as in Krehbiel (1996). Congress first proposes a new spending proposal for the entire farm bill. The House passes the proposal by a simple majority rule, but a Senate minority can block the bill using a filibuster. To overcome a filibuster (invoke cloture), the passage of the proposal requires 3/5 majority in the Senate. After the passage of the proposal in both chambers, the president can veto the bill. Otherwise, the new bill is implemented and replaces the status quo. In case of a presidential veto, Congress should gather $2 / 3$ majority to override it. If so, the bill is implemented. If Congress fails to gather the $2 / 3$ votes, the proposal fails and the status quo rules. The reversion point is assumed to be current farm programs as Congress can use a continuing resolution when it fails to write a new farm bill.

${ }^{10}$ A detailed discussion of the game using examples of farm bill Congresses is available in the appendix.
} 
program spendings. We explain why this is the case in the following.

First, the U.S. Congress is a majoritarian institution. The majority party wields disproportional power over the minority. Members of the majority party chair all committees, and the party's leadership influences committee assignments. While congressional committees have important institutional powers such as gatekeeping and proposal and veto rights, these powers are significantly limited by the majority leadership of the parent chamber (Sinclair 1983; Cox and McCubbins 1993; Sinclair 1995; Deering and Smith 1997).

Second, two chambers of the U.S. Congress share power in the legislative process of farm bills. Farm bills are highly complex pieces of legislation that often result in significant differences between House and Senate versions. Differences between two versions, therefore, have been adjusted in conference committees. Congressional scholars observe that conferees are picked by majority leaders. As a result, preferences of the conferees are often highly aligned with those of party leaders (Smith 1988; McQuillan and Ortega 1992; Deering and Smith 1997; Vander Wielen 2010).

Moreover, the opportunity cost of rejecting the conference report is usually high because conference is the only way to resolve differences between each chamber's farm bills before adjournment. Once the conference committee reaches an agreement, the conference report must pass by a simple up-or-down vote in both houses. ${ }^{11}$ Rejecting a farm bill conference report is particularly risky because the reversion points are commodity programs put forward in the 1938 and 1949 laws, programs that would be prohibitively expensive.

Interestingly, many of the partisan battles over farm bills have been waged over food stamp legislation more often than farm support programs. As the budget size of food stamp programs grew bigger and bigger, Republicans made food stamp programs as partisan flashpoints in their ideological fight for government budget cuts. And in these partisan battles, the unified control of Congress (or government) has indeed been instrumental in increasing or restricting access to the food stamp program. For example, in the Food Stamp Act of 1977, which was passed as a part of the 1977 farm bill by a unified Democratic government, the Democratic Congress eliminated the program's purchase requirement, which had previously served as a major barrier to participation. ${ }^{12}$ Republicans, wanting to limit the food stamp program to only the neediest recipients, opposed the elim-

\footnotetext{
${ }^{11}$ Technically, conference reports can be filibustered in the Senate.

12 The Food Stamp Act of 1964 required that all the "recipients purchase their food stamps, paying an amount commensurate with their normal expenditures for food and receiving an amount of food stamps representing an opportunity more nearly to obtain a low-cost nutritionally adequate diet" (Department of Agriculture 2013).
} 
ination of the purchase requirement (King 2000).

Another important partisan battle over the food stamp program surrounded the 1996 farm bill and featured a bicameral Republican majority facing Democratic President Bill Clinton. The Republican Congress attempted to remove recipients' entitlements to the food stamp program, but succeeded only in decreasing the size of the program in the face of a presidential veto threat, which we will discuss in detail later in this article. ${ }^{13}$

If we combine the foregoing discussions about the conditions for changes of farm bill spending at the national level, which we call aggregate changes and the dynamics within divided governments regarding changes in the relative size of the two core farm bill programs, we can predict the effect of the party composition of government on changes in the size of food stamp programs vis-à-vis farm support programs as follows:

1. Unified Government Hypothesis: A significant change in the aggregate size offarm bill spending should occur under unified government at the time offarm bill reauthorization.

2. Unified Congress Hypothesis: When a party has a majority in both houses at the time of farm bill reauthorization facing an opponent party's president, an increase in the size of the food stamp program leads to a proportional decrease in the size of farm support programs, or vice versa.

\section{DATA AND METHOD}

We collect county-level farm payments data and food stamp benefits data from the Regional Economic Information System (REIS) maintained by the Bureau of Economic Analysis (Bureau of Economic Analysis, Regional Economic Accounts). The data sets record the distribution of farm payments and food stamp program benefits based on the physical addresses of payment recipients, not the locations of their farms. The data reflect government payments through farm commodity programs, export programs, conservation programs, and crop insurance programs. For temporal comparisons, analyzing payments by county is a better strategy than using congressional districts, which change much more frequently through partisan redistricting and population migration.

We use geographic correspondence information provided by MABLE/

\footnotetext{
${ }^{13}$ See King (2000) for an excellent historical description of the politics of food stamp programs in the United States.
} 
Geocorr9o Geographic Correspondence Engine to find what portion of counties is located within a congressional district. The MABLE/Geocorr9o Geographic Correspondence Engine computes allocation factors of all counties for respective congressional districts using geographical information such as the size of the land area and the number of residents within the boundary. The MABLE/Geocorr geographic correspondence engine generates files showing the relationships between a wide variety of geographic coverages for the United States (MABLE/ Geocorr 1997).

To find associations between party control and the farm bill's two major pieces requires us to devise a research design that identifies systematic departures from "normal" payments, or the payments that counties would receive independent of which party controls Congress. We employ two methods to control for "normal" payments. First, we difference the dependent variable using previous payment data at the county level. A county's previous farm payments are computed by averaging payments received over the three years prior to the farm bill year. ${ }^{14}$ Current farm payments are computed by averaging payments received over the two years after the bill's passage. Since payments during the farm bill year are likely to be affected both by the previous and the newly enacted bills, they are not included in either calculation in order to avoid measurement error.

Two-year averages are used to minimize measurement error caused by o-farm bill year legislation. For example, Congress often passes emergency legislation or supplementary legislation providing additional income support when there are unexpected events such as natural disasters or commodity price changes. This type of legislation is less directly related to party control of Congress at the time of the farm bill's passage. In contrast, the food stamp program has been reauthorized along with farm subsidies in every omnibus farm bill since 1973. In addition, the few pieces of supplementary legislation that have been passed have not impacted the specifics of this program during off-farm bill years. Thus, each county's average food stamp benefits are computed by taking the average of the benefits over the entire farm bill period.

The key explanatory variables are two dummy variables indicating majority party membership in the House of Representatives (Majority) and unified party control of Congress (unified Congress). To see the interaction effect of partisanship with party control of Congress, we include a dummy variable for the Republican Congress, which is coded as 1 when the Republican party holds majority in both chambers and o otherwise. Variables for membership on the two House committees more relevant to agriculture issues, Agriculture and

\footnotetext{
${ }^{14}$ Using the two-year average does not change the substantive conclusion of the results.
} 
Appropriations, are also included. Counties represented by members of these two committees are expected to be different from other counties not represented in terms of farm payment and food stamp benefit changes. For congressional committee membership, we combine two sources; the first comes from Garrison Nelson (n.d.), the second from Charles Stewart and Jonathan Woon (2009).

We use ordinary least squares (OLS) for the pooled analysis of the food stamp benefits and farm payments. ${ }^{15}$ We include state fixed effects to control for timeconstant state-specific factors such as the overrepresentation of small farm states in the Senate.

The dependent variables are payment data, while the explanatory variables are mostly dummy variables. Thus, we log transformed the dependent variables for a better fit. The resulting statistical model can be written as follows:

$$
\begin{aligned}
\log \left(\Delta y_{i j t}\right)= & \alpha_{j}+\text { Unified Congress }_{i j t} \beta_{1}+\text { Majority }_{i j t} \beta_{2}+ \\
& \text { Majority }_{i j t} \times \text { Unified Congress }_{i j t} \beta_{3}+\text { Control Variables }_{i j t} \gamma+\epsilon_{i j t} \\
\epsilon_{i j t} \sim & \mathcal{N}\left(0, \sigma^{2}\right) \\
\Delta y_{i j t}= & y_{i j, \text { new }}-y_{i j, \text { old }} \\
y_{i j, \text { new }}= & \frac{y_{i j, t+1}+y_{i j, t+2}}{2} \\
y_{i j, \text { old }}= & \frac{y_{i j, t-1}+y_{i j, t-2}+y_{i j, t-3}}{3}
\end{aligned}
$$

where $i$ indicates a county, $j$ indicates a state, $t$ indicates a farm bill year, and $\alpha$ is state fixed-effects.

\section{EMPIRICAL RESULTS}

\section{AGGRAGATE CHANGES IN PROGRAM BENEFITS}

Table 2 reports the partisan distributions of farm payments and food stamp benefits between 1973 and 2002. Columns 2 and 3 report the number of congressional districts receiving farm bill benefits of more than $\$ 5,000$. Columns 4 and 5 report district means, while columns 6 and 7 show the total benefits received by

\footnotetext{
${ }^{15}$ Although our dependent variables are compositional data, OLS produces consistent estimates as generalized least squares for the seemingly unrelated regression model because each of our regression models has identical covariates (See Greene 2000, 616-617).
} 
districts from each party (not including counties receiving less than $\$ 5,000$ ).

Table 2. Distribution of Farm Payments and Food Stamp Benefits by Party

\begin{tabular}{|c|c|c|c|c|c|c|}
\hline \multirow[b]{3}{*}{ Year } & \multicolumn{6}{|c|}{ Farm Payments } \\
\hline & \multicolumn{2}{|c|}{ Districts } & \multicolumn{2}{|c|}{ District Means (million \$) } & \multicolumn{2}{|c|}{ Party Total (million \$) } \\
\hline & Democrat & Republican & Democrat & Republican & Democrat & Republican \\
\hline 1973 & 135 & 134 & 2.14 & 2.33 & 288.32 & 312.47 \\
\hline 1977 & 181 & 111 & 6.03 & 8.18 & 1090.60 & 907.81 \\
\hline 1981 & 154 & 149 & 17.02 & 20.81 & 2620.37 & 3100.43 \\
\hline 1985 & 167 & 147 & 30.09 & 54.58 & 5025.80 & 8023.35 \\
\hline 1990 & 172 & 140 & 19.82 & 30.28 & 3409.19 & 4239.15 \\
\hline 1996 & 124 & 174 & 34.14 & 42.79 & 4232.74 & 7445.94 \\
\hline \multirow[t]{3}{*}{2002} & 116 & 166 & 32.88 & 46.76 & 3814.55 & 7761.67 \\
\hline & \multicolumn{6}{|c|}{ Food Stamp } \\
\hline & \multicolumn{2}{|c|}{ Districts } & \multicolumn{2}{|c|}{ District Means (million \$) } & \multicolumn{2}{|c|}{ Party Total (million \$) } \\
\hline Year & Democrat & Republican & Democrat & Republican & Democrat & Republican \\
\hline$\overline{1973}$ & 166 & 150 & 15.07 & 10.12 & 2501.25 & 1518.21 \\
\hline 1977 & 200 & 115 & 21.81 & 15.02 & 4362.63 & 1727.37 \\
\hline 1981 & 169 & 157 & 35.11 & 25.95 & 5933.78 & 4074.84 \\
\hline 1985 & 181 & 154 & 38.14 & 25.13 & 6902.94 & 3869.72 \\
\hline 1990 & 185 & 145 & 70.81 & 50.52 & 13100.77 & 7325.70 \\
\hline 1996 & 133 & 179 & 63.55 & 36.86 & 8452.15 & 6598.65 \\
\hline 2002 & 127 & 170 & 103.89 & 63.05 & 13194.14 & 10718.86 \\
\hline
\end{tabular}

Source: Regional Economic Information System, Bureau of Economic Analysis.

Note: The matching process between counties and congressional districts generated some missing districts. For the comparability across farm bills with unbalanced payment periods, we use the average of first two years' payments in each farm bill. Districts indicate the number of districts receiving over $\$ 5,000$ benefits.

Payments are reported in millions of dollars.

As farm payments are reported at the county level, we compute the amount of farm payments owing to Democratic districts by summing county-level payments at the district level. Let be the total number of Democratic districts receiving farm payments over $\$ 5,000$ and be the number of payment-receiving counties at district i. Then, the total amount of payment going to the Democratic Party is computed as follows:

$$
\text { Payment to the Democratic Party }=\sum_{i=1}^{N_{D}}\left(\sum_{j}^{J_{i}} \text { county payment }_{j}\right)
$$

Food stamp benefits are computed in the same way as farm payments.

Two clear patterns arise from the analysis. First, while farm support programs heavily benefited Democratic districts in the 1970s, the amount of farm payments going to Republican districts have been larger than that going to Democratic districts since the 1980s. In the 1996 and 2002 farm bills, Republicans received larg- 
er farm payments than Democrats both in terms of the number of paymentreceiving districts (the second and third columns in Table 2) and in terms of the total amount of payments (the sixth and seventh columns in Table 2).

Second, Democrats are more dependent upon food stamp benefits than Republicans over time. In the 1970 s and 1980 s, the partisan difference in the size of food stamp program benefits was small. However, the average amount of food stamp benefits going to a Democratic district has become much larger than that going to a Republican district since the 1990s. The total food stamp benefits received by Democratic districts are also much larger than those received by Republican districts. ${ }^{16}$

Considering this asymmetric distribution of farm bill benefits between the two parties, it is reasonable to expect that party leaders would have a strong incentive to change the relative size of the two programs in favor of their party's districts.

Historical changes in the size of program benefits provide evidence of these partisan tendencies. The top panel in Figure 1 shows aggregate changes in food stamp benefits since 1969, while the bottom panel shows aggregate changes in farm payments over the same period. The dark vertical lines indicate unified party control of Congress by Democrats and the light vertical lines at 1996 indicate unified Republican control of Congress. The dotted lines indicate divided party control of Congress. It is clearly shown that the unified Democratic Congresses were important moments for the growth of the food stamp program over time; in the three historical cases where Democrats controlled both houses of Congress (1973, 1977, and 1990), food stamp benefits increased. In contrast, unified Republican control of Congress in the 1996 farm bill led to a significant fall in food stamp benefits until 2000. However, the changes in the size of farm payments shown in the bottom panel of Figure 1 do not reveal any clear partisan pattern. One notable pattern is the dramatic increase in farm payments that came three years after the 1996 farm bill. ${ }^{17}$

${ }^{16}$ Explaining the causes of the partisan switches is beyond the scope of this study. We conjecture that these partisan switches are closely related with the partisan realignment started by the Civil Rights and Voting Rights Acts (Sundquist 1983; Miller and Schofield 2003). Observers of American politics commonly note that Southern agrarian states, which were core supporters of the New Deal coalition, have since moved toward the Republican Party (Wattenberg 1991; Nadeau and Stanley 1993; Miller and Schofield 2003; McCarty, Poole and Rosenthal 2006; Miller and Schofield 2008; Jacobson 2010).

${ }^{17}$ The cause of this dramatic increase will be explained in our case study of the 1996 farm bill. 
Figure 1. Changes in Total Benefits of the Food Stamp Program and Farm Programs
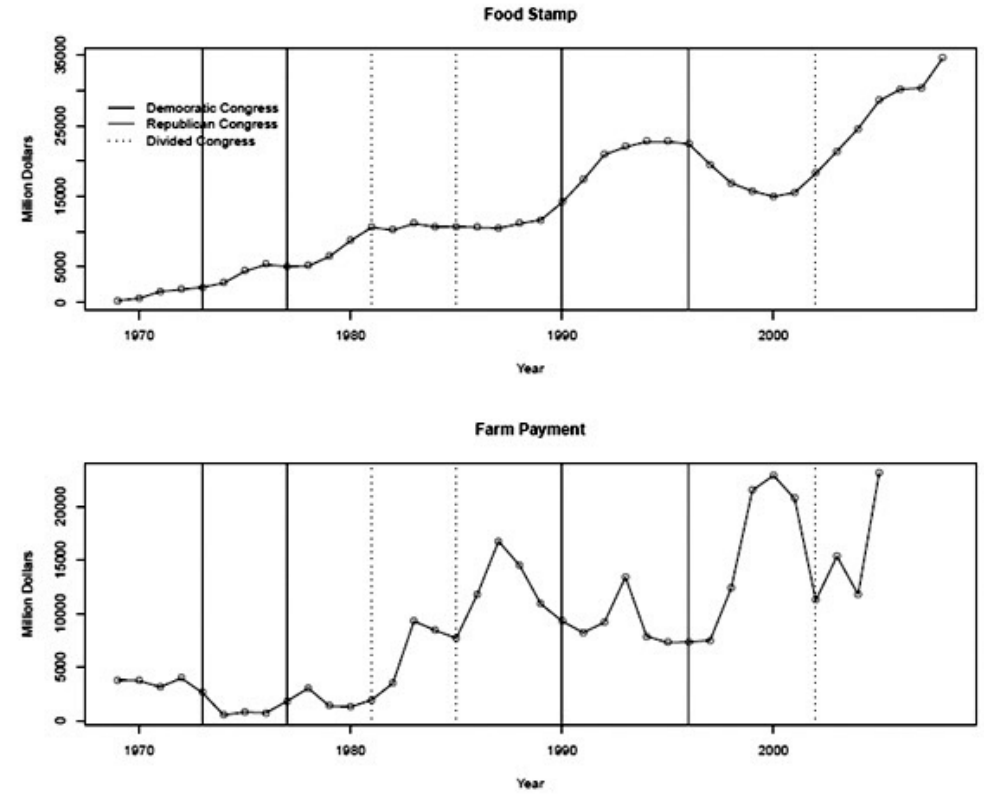

Source: Regional Economic Information System, Bureau of Economic Analysis.

Note: Vertical lines indicate seven omnibus farm bill years. Dotted lines indicate divided party control of Congress and solid lines indicate unified party control of Congress.

Figure 2 shows the density plots of net aggregate changes across four different types of partisan government. First, the two plots in the first column show that the unified Democratic government that passed the 1977 farm bill dramatically increased both farm payments and food stamp benefits. As we predicted from our theory, these simultaneous increases in both programs were possible because of the presence of a co-partisan president. The second column clearly demonstrates that the two unified Democratic Congresses in 1973 and 1990 increased food stamp program benefits while decreasing farm payments. Faced with a Republican president's veto threat, Democratic Congresses could not expand both programs' benefits. Therefore, they chose to increase only the food stamp program, which disproportionately favored districts represented by incumbent Democrats. To put it differently, these cutbacks in farm payments were a tradeoff that Democratic Congresses had to make in order to expand the food stamp program under Republican presidents. The third column displays the opposite partisan pattern.

The Republican Congress shrunk the food stamp program while handing out 
more farm payments. Again, the increase in farm payments was the price Republicans paid to pass a highly partisan farm bill that slashed food stamps. Finally, divided party control of Congress - shown in the fourth column of Figure 2-does not produce any consistent pattern in the distribution of farm payments and food stamp benefits.

Figure 2. Net Changes in Farm Payments and Food Stamp Benefits at the County Level Across Six Omnibus Farm Bills Since 1977
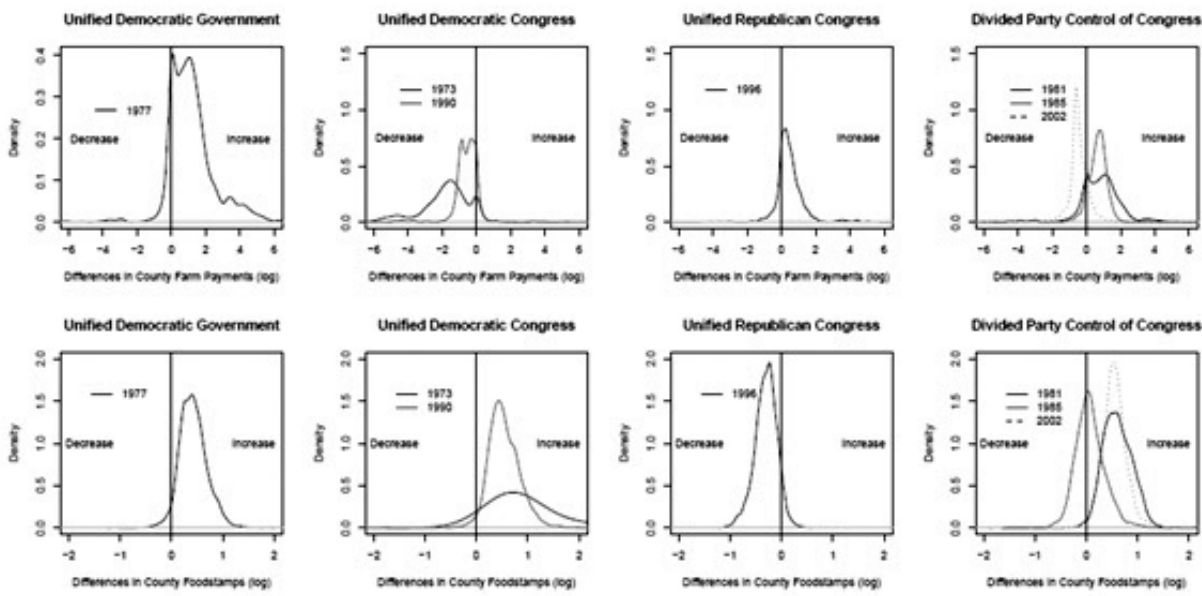

Source: Regional Economic Information System, Bureau of Economic Analysis.

Note: The 1973 farm bill was dropped because farm bills prior to 1973 were not comparable to the 1973 farm bill. Above all, pre-1973 farm bills did not include the food stamp program. The curved lines indicate the densities of net changes in log transformed farm payments in each county. The right hand side of the vertical bar, indicating no change, is increased payments and the left hand side of the vertical bar is decreased payments.

\section{POOLED REGRESSION ANALYSIS OF COUNTY-LEVEL BENEFITS}

Table 3 summarizes the regression analysis of farm payments and food stamp benefits at the county level across seven omnibus farm bills. As we expected, the signs for the effect of unified party control of Congress (unified Congress) are reversed between farm payments and food stamp benefits. First, the effect of a unified Democratic Congress on the size of farm support programs is always negative. If we control for the positive effect of a Republican Congress (Model 4 and Model 5 in the top panel of Table 3), Democratic Congresses without a Democratic president tend to decrease farm payments across counties while the Republican Congress increases farm payments.

In contrast, the effect of the unified Congress variable is consistently positive with regard to food stamp benefits, as shown in the bottom panel of Table 3 . The Republican Congress decreased food stamp benefits quite dramatically while the 
Democratic Congresses always increased them. Note that Democrats received more from the increases when they controlled Congress. Reading from the bottom of Model 5, counties represented by Democrats received 16\% more than counties represented by Republicans when the Democratic Party controlled both houses of Congress. As the dependent variable is log transformed, coefficients should be exponentiated to compute the effect size.

For example, the coefficient for the benefits to House Democrats is 0.15. Then, being represented by a House Democrat increases benefits by $16 \%$ as $\exp (0: 15)=$ 1:16. The Republican Congress that passed the 1996 farm bill made significant cuts to food stamp benefits in all counties. On average, it decreased food stamp benefits to Democratic and Republican counties by $54 \%$ and $49 \%$, respectively.

Table 3. Pooled OLS Analysis of Party Control of Congress and the Distribution of Farm Payments and Food Stamp Benefits at the County Level

\begin{tabular}{|c|c|c|c|c|c|}
\hline Dependent Variable: Farm P & $\begin{array}{l}\text { Mments } \\
\text { Model } 1\end{array}$ & Model 2 & Model 3 & Model 4 & Model 5 \\
\hline Constant & $\begin{array}{r}0.16^{\circ} \\
(0.07)\end{array}$ & $\begin{array}{c}0.10 \\
(0.07)\end{array}$ & $\begin{array}{c}0.19^{* *} \\
(0.07)\end{array}$ & $\begin{array}{c}0.20^{* *} \\
(0.07)\end{array}$ & $\begin{array}{l}0.23^{* * *} \\
(0.06)\end{array}$ \\
\hline Unified Congress & $\begin{array}{c}-0.51^{\cdots} \\
(0.02)\end{array}$ & $\begin{array}{l}-0.51 \cdots \\
(0.02)\end{array}$ & $\begin{array}{l}-0.65 \cdots \\
(0.03)\end{array}$ & $\begin{array}{l}-0.85^{* *} \\
(0.03)\end{array}$ & $\begin{array}{l}-1.57^{* * *} \\
(0.03)\end{array}$ \\
\hline Majority & & $\begin{array}{c}0.03 \\
(0.02)\end{array}$ & $\begin{array}{l}-0.11 \cdots \\
(0.03)\end{array}$ & $\begin{array}{c}-0.11 \cdots \\
(0.03)\end{array}$ & $\begin{array}{l}-0.11^{* \cdots} \\
(0.03)\end{array}$ \\
\hline Unified Congress $\times$ Majority & & & $\begin{array}{l}0.25 \cdots \\
(0.04)\end{array}$ & $\begin{array}{l}0.23 \cdots \\
(0.04)\end{array}$ & $\begin{array}{l}0.11^{\bullet \bullet} \\
(0.04)\end{array}$ \\
\hline Republican Congress & & & & $\begin{array}{l}0.87^{\cdots \cdots} \\
(0.03)\end{array}$ & $\begin{array}{l}1.66^{* * *} \\
(0.03)\end{array}$ \\
\hline Democratic Government & & & & & $\begin{array}{l}2.34 * * \\
(0.03)\end{array}$ \\
\hline Agriculture & & $\begin{array}{l}0.18^{* \cdots} \\
(0.03)\end{array}$ & $\begin{array}{l}0.18^{\cdots \cdots} \\
(0.03)\end{array}$ & $\begin{array}{l}0.16^{\cdots \cdots} \\
(0.03)\end{array}$ & $\begin{array}{l}0.12^{* *} \\
(0.02)\end{array}$ \\
\hline Appropriations & & $\begin{array}{l}0.03 \\
(0.03)\end{array}$ & $\begin{array}{c}0.03 \\
(0.03)\end{array}$ & $\begin{array}{c}0.02 \\
(0.03)\end{array}$ & $\begin{array}{r}-0.05^{\dagger} \\
(0.03)\end{array}$ \\
\hline State Fixed Effects & Yes & Yes & Yes & Yes & Yes \\
\hline$N$ & 19835 & 19835 & 19835 & 19835 & 19835 \\
\hline$R^{2}$ & 0.04 & 0.04 & 0.05 & 0.08 & 0.33 \\
\hline adj. $R^{2}$ & 0.04 & 0.04 & 0.04 & 0.08 & 0.32 \\
\hline Resid. sd & 1.45 & 1.45 & 1.45 & 1.42 & 1.21 \\
\hline Dependent Variable: Food S & $\begin{array}{l}\text { mp Benefits } \\
\text { Model } 1\end{array}$ & Model 2 & Model 3 & Model 4 & Model 5 \\
\hline Constant & $\begin{array}{l}0.67^{\cdots *} \\
(0.05)\end{array}$ & $\begin{array}{l}0.71^{\cdots} \\
(0.06)\end{array}$ & $\begin{array}{l}0.74^{\cdots} \\
(0.06)\end{array}$ & $\begin{array}{l}0.72^{* *} \\
(0.05)\end{array}$ & $\begin{array}{l}0.72^{* * *} \\
(0.05)\end{array}$ \\
\hline Unified Congress & $\begin{array}{l}0.35 \cdots \\
(0.02)\end{array}$ & $\begin{array}{l}0.35 \cdots \\
(0.02)\end{array}$ & $\begin{array}{l}0.29 \cdots \\
(0.03)\end{array}$ & $\begin{array}{l}0.65 \cdots \\
(0.02)\end{array}$ & $\begin{array}{l}0.95 * * \\
(0.02)\end{array}$ \\
\hline Majority & & $\begin{array}{c}0.02 \\
(0.02)\end{array}$ & $\begin{array}{c}-0.04 \\
(0.03)\end{array}$ & $\begin{array}{c}-0.03 \\
(0.02)\end{array}$ & $\begin{array}{l}-0.03 \\
(0.02)\end{array}$ \\
\hline Unified Congress $\times$ Majority & & & $\begin{array}{l}0.10^{\circ} \\
(0.03)\end{array}$ & $\begin{array}{l}0.09^{* *} \\
(0.03)\end{array}$ & $\begin{array}{l}0.15 * \cdots \\
(0.03)\end{array}$ \\
\hline Republican Congress & & & & $\begin{array}{l}-1.39 \cdots \\
(0.02)\end{array}$ & $\begin{array}{l}-1.73^{* *} \\
(0.02)\end{array}$ \\
\hline
\end{tabular}




\begin{tabular}{lccccc}
\hline \hline Dependent Variable: Food Stamp Benefits & Model 1 & Model 2 & Model 3 & Model 4 & Model 5 \\
\hline Democratic Government & & & & & $-1.02^{* * *}$ \\
& & & & & $(0.02)$ \\
Agriculture & & $-0.16 * *$ & $-0.16^{* *}$ & $-0.12^{\cdots *}$ & $-0.10^{* *}$ \\
& & $(0.02)$ & $(0.02)$ & $(0.02)$ & $(0.02)$ \\
Appropriations & & $-0.07 *$ & $-0.07 *$ & $-0.05 *$ & -0.03 \\
& & $(0.03)$ & $(0.03)$ & $(0.02)$ & $(0.02)$ \\
State Fixed Effects & Yes & Yes & Yes & Yes & Yes \\
$N$ & 18825 & 18825 & 18825 & 18825 & 18825 \\
$R^{2}$ & 0.06 & 0.07 & 0.07 & 0.21 & 0.28 \\
adj. $R^{2}$ & 0.06 & 0.06 & 0.07 & 0.21 & 0.27 \\
Resid. sd & 1.16 & 1.16 & 1.16 & 1.07 & 1.02 \\
\hline \hline
\end{tabular}

Note: The dependent variable for the top table is farm payments and the dependent variable for the bottom table is food stamp benefits. Payment data are log transformed and differenced using the previous payment data at the same county to control for normal payments at each county. State fixed-effects are included but are not reported to save space. Standard errors in parentheses. $\phi " p<.10 ;{ }^{*} p<.05 ;{ }^{* *} p<.01 ;{ }^{* * *} p<.001$.

Another important finding from Table 3 is the effect of unified Democratic government. The 1977 farm bill increased farm payments by as much as $116 \%$ for all counties, while cutting food stamp benefits by $7 \%$ for Republican counties and increasing them by $5 \%$ to $8 \%$ for Democratic counties. On a more counterintuitive note, Agriculture Committee membership had opposite effects for the two dependent variables. Counties represented by Agriculture Committee members received $12 \%$ to $19 \%$ additional increases in farm payments, but $10 \%$ to $15 \%$ decreases in food stamp benefits. We believe that these reductions in food stamp benefits within Agriculture Committee members' districts are likely to be correlated with population declines in rural areas.

\section{ALTERNATIVE MODEL SPECIFICATIONS}

To check the robustness of the findings from the fixed-effects method, we also fit a varying intercept model using state as a second level, as recommended by Gelman and Hill (2007). The varying intercept model allows the intercept to randomly vary across states to account for unobserved heterogeneity within each state. This is identical to the random-effects model. The model can be shown as follows:

$$
\begin{aligned}
& \log \left(\Delta y_{i j t}\right)= \alpha_{j}+\text { Unified Congress }_{i j t} \beta_{1}+\text { Majority }_{i j t} \beta_{2}+ \\
& \text { Majority }_{i j t} \times \text { Unified Congress }_{i j t} \beta_{3}+\text { Control Variables }_{i j t} \gamma+\epsilon_{i j t} \\
& \epsilon_{i j t} \sim \mathcal{N}\left(0, \sigma_{\text {county }}^{2}\right) \\
& \Delta y_{i j t}= y_{i j, \text { new }}-y_{i j, \text { old }} \\
& \alpha_{j} \sim \mathcal{N}\left(\alpha_{0}, \sigma_{\text {state }}^{2}\right)
\end{aligned}
$$

where $i$ indicates a county, $j$ indicates a state, and $t$ indicates a farm bill Congress. 
Table 4 shows the results of the random intercept model. The results are consistent with those from the fixed-effect method. Unified Congress, which indicates the unified Democratic control of Congress, is statistically significant and has opposite signs in two programs. Republican Congress is also statistically significant and has opposite signs in two programs. These findings imply that the unified party control of Congress has opposite effects on the food stamp benefits and farm subsidies. Most importantly, Unified Congress and Republican Congress point opposite directions in each program, implying that the effects of Republican Congress is opposite to those of Democratic Congress as predicted by our partisan story.

Table 4. Varying Intercept Model for Party Control of Congress and the Distributions of Farm Payments and Food Stamp Benefits

\begin{tabular}{lrrrr}
\hline \hline & \multicolumn{2}{c}{ Farm Payment } & \multicolumn{2}{c}{ Food Stamp } \\
County Level & Estimate & Std. Error & Estimate & Std. Error \\
\hline Constant & 0.414 & 0.035 & 0.425 & 0.041 \\
Unified Congress & -1.567 & 0.028 & 0.951 & 0.025 \\
Majority & -0.117 & 0.027 & -0.030 & 0.023 \\
Unified Congress $\times$ Majority & 0.110 & 0.035 & 0.148 & 0.031 \\
Republican Congress & 1.657 & 0.028 & -1.726 & 0.024 \\
Democratic Government & 2.343 & 0.028 & -1.023 & 0.024 \\
Agriculture & 0.114 & 0.022 & -0.103 & 0.019 \\
Appropriations & -0.047 & 0.026 & -0.025 & 0.023 \\
\hline State Level & Variance & Std.Dev & Variance & Std.Dev \\
\hline Constant & 0.033 & 0.183 & 0.058 & 0.241 \\
Residual & 1.475 & 1.214 & 1.041 & 1.020 \\
\hline \hline
\end{tabular}

We also analyzed the final passage votes on farm bills. The associations between members' party affiliations and vote choices are statistically significant at the $95 \%$ confidence level in five farm bills reauthorized under unified Congresses. However, vote choices in final passage votes are affected by many factors and effect sizes vary substantially across the five cases of unified Congresses. Thus, we do not view these results as strong and convincing evidence in favor of our theory, though they are suggestive. ${ }^{18}$

Overall, the results from various quantitative methods are consistent with our partisan story regarding changes in the size of food stamp program and farm support programs in response to the party composition of Congress and the presidency.

18 The results of the roll call data analysis are reported in the appendix. 


\section{THE 1996 FARM BILL IN FOCUS}

In this section, we examine our partisan story by taking a close look at the 1996 farm bill. The 1996 farm bill is an interesting case to look at because it was the first case of unified Republican control of Congress at the time of a farm bill authorization since 1973. Thus, the 1996 farm bill provides a test of whether the Republican bicameral majority generated policy outcomes consistent with our partisan theory.

For the first time since the New Deal, Republican congressional leaders in the 104th Congress had a chance to structure the farm bill in a partisan manner that benefited their members. House Speaker Newt Gingrich promised to return market forces to the "East German socialist" farm programs and to "reform" the food stamp program (New York Times 2001). Outlined in their signature document, the "Contract With America," Republicans sought to enact an agenda that reduced welfare spending and devolved statutory authority to the states (Weaver 1996).

Strong party discipline and a homogeneous membership_combined with the procedural advantages of a bicameral majority-made it possible for the Republican Congress to modify the food stamp program and farm programs significantly. Among some of the changes Congress made were eliminating most legal immigrants' eligibility for food stamps, placing a time limit on food stamp receipt, reducing the maximum allotments of food stamps, decoupling government farm payments from market price changes, ending acreage reduction programs and planting restrictions, and phasing out the dairy price support programs (Gundersen, Leblanc and Kuhn 1999; Becker 2002).

Food stamps, however, proved to be a wedge issue dividing Republican leaders who wanted to reduce benefits from rank-and-file Republicans representing poor districts. To broker a compromise, Republican leaders' attempted to transform the food stamp program into state block grants, which would end the entitlement status of the Aid to Families with Dependent Children. However, a bipartisan coalition defeated this measure in committee and on the floors of both houses. ${ }^{19}$ Then subsequent Congresses also controlled by Republicans restored many of the cuts and changes to food stamp benefits. For example, on May 22, 1998, 98 Republicans joined 190 Democrats to defeat the attempt of the Republican lead-

${ }^{19}$ For a detailed description of the compromise, see King (1999). According to King (1999), "The House Agriculture Committee voted 5-37 against transforming food stamps into a block grant. A block grant amendment offered on the House floor failed 114-316, with Republicans divided almost evenly and Democrats opposed almost unanimously. The Senate Agriculture Committee similarly refused the block grant option, and a substitute motion on the Senate floor failed 36-64, with one-third of Republicans joining the Democrats by voting against it” (King 1999, 370). 
ership to amend the conference agreement on some legal immigrants' eligibility to receive food stamps (New York Times 1998). Likewise, bipartisan coalitions in the 105th and 106th Congresses eased program restrictions.

Republican farm program "reforms" were similarly modified once agricultural prices started to fall the following year. Since the 1996 farm bill had severed the linkage between farm payments and changes in market prices, farmers' incomes fell dramatically when commodity prices plunged between 1997 and 1999. Democratic legislators did not hesitate to blame the fall in prices on the Republican reforms..$^{20}$ In response, the Republican Congress restored most cuts to the 1996 farm bill through supplementary legislation passed during the 105th and 106th Congresses. ${ }^{21}$ Thus, the landmark reforms of the 1996 farm bill quickly evaporated in favor of a return to the status quo.

The 1996 farm bill illustrates key elements of our theory. As we predicted, the Republican ideological "reform" of the food stamp and farm programs was possible largely because Republicans controlled both houses. Republican leaders used their powers in the House and Senate Agriculture Committees, the House Rules Committee, and the farm bill conference committee to structure the bill according to principles sketched out in the Contract With America. As we explained, Republican leaders'-especially House Speaker Newt Gingrich'sinfluence over committee chairs and the legislative agenda served as the main vehicle for implementing the Party's agenda into the bill. However, in the presence of veto threats by President Clinton over welfare reforms and budget issues, the Republican leadership had to compromise with moderate Republicans and Democrats.

The Republican leadership's control of the process allowed for some cuts in food stamp benefits. Yet, despite the public rhetoric, there was a dramatic increase in allocations of farm payments. These changes had the effect of reallocating more federal dollars to Republican controlled districts, made possible by the cooptation of moderate Democrats in the face of a threatened presidential veto.

${ }^{20}$ Here we requote the Democratic Party platform in the 1996 presidential election: "The Republican Freedom to Farm Act has resulted in years of low prices and necessitated billion dollar bailouts. It is misguided and must be changed."

${ }^{21}$ For example, the Emergency Farm Financial Relief Act of 1998 (P.L. 105-228) released $\$ 5.5$ billion to farmers on August 12, 1998. Then, the Omnibus Consolidated and Emergency Appropriations Act (P.L. 105-277) provided \$5.9 billion on October 21, 1998; the Agriculture Appropriations Act (P.L. 106-178) on October 22, 1999, provided $\$ 8.7$ billion; the Agricultural Risk Protection Act of 2000 (P.L. 106-224) on June 20 provided \$7.1 billion in emergency farm assistance; the Agriculture Appropriations Act (P.L. 106-387) on October 28, 2000, released another \$3.5 billion; and the Agricultural Economic Assistance Act (P.L. 107-125) on August 13, 2001, provided a final $\$ 5.5$ billion in emergency farm assistance. 


\section{CONCLUSION}

In this article, we showed how the partisan composition of government has affected the distribution of farm bill benefits in the United States. We argued the inclusion of the food stamp program in omnibus farm bills beginning in the early $1970 \mathrm{~s}$ as an important factor generating a trade-off between expansion of farm support programs and that of food stamp benefits. This trade-off becomes salient when Congress is unable to increase the total budget of a farm bill. We argued that unified party control of government (both Congress and the presidency) is necessary for the simultaneous expansion of both programs, given the multiple veto points in the farm bill process. In cases of divided government, we predicted that the presence of a bicameral majority is necessary for the expansion of one program's benefits at the expense of the other.

We acknowledge that it is difficult to find conclusive quantitative evidence for our institutional claims due to the short history of modern omnibus farm bills. However, we found a variety of empirical evidence in favor of our claims by analyzing temporal changes in aggregate program benefits and finding partisan patterns in the distribution of program benefits at the county level.

First, changes in program benefits at the aggregate level are largely consistent with our predictions; the unified Democratic government in 1977 dramatically increased both farm payments and food stamp benefits, while Democratic Congresses facing Republican presidents in 1973 and 1990 were able to expand food stamp benefits only at the expense of farm support benefits. In contrast, the Republican Congress at the time of the 1996 farm bill shrunk the food stamp program while handing out more farm payments. A close examination of the events that followed the 1996 farm bill - actions undertaken by Republican Congressesfurthersupported our theoretical conjecture.

Second, this partisan story is consistent with general patterns in the distribution of county-level program benefits between 1973 and 2002; unified Democratic Congresses tended to decrease the size of farm payments and increase food stamp program benefits, while the Republican Congress of 1996 increased farm payments and decreased food stamp benefits.

A decrease in farm support benefits under a unified Democratic Congress facing a Republican president is counterintuitive to political observers who would consider the Democratic Party to be pro-farm support and the Republican Party to be anti-farm support. Taking a recent example, in the 2008 presidential election, Republican presidential candidate John McCain publicly opposed the 2008 farm bill being prepared in Congress while Democratic presidential candidate Barack Obama favored it. ${ }^{22}$ We believe that our theory - by focusing on the inter- 
play between the bicameral Congress, the president, and the interdependent nature of food stamp and farm support policymaking - provides a consistent explanation of historical changes in U.S. agriculture policy. Agriculture policy in the United States is certainly highly complex and has multidimensional aspects as Browne (1995) notes. However, we believe that partisanship is a central, though subtle, factor in U.S. agriculture policy, as it is with numerous other public policy issues.

What we found from the U.S. case has broader implications to comparative study of agriculture policy. First, the United States is a hard case to test a partisan theory of agricultural protection in that the United States has weak party system in a comparative perspective (McGillivray 1997) and a relatively low level of agricultural protection (Park and Jensen 2007). We believe that the influence of party is omnipresent in everyday legislative politics, regardless of the form of party control in Congress. We may not always observe the influence of party in policy outcomes since the logic of political competition pits the effect of one party against the effect of the other party, the net effect of which is often transient, temporary, and minuscule. What we demonstrate in this study is that unified party control of both houses in U.S. Congress is a condition under which the countervailing force of minority parties or opposing parties' Presidents is significantly weakened in the protection of agriculture.

Second, the key findings of this study shed new light on the divided government hypothesis in the literature of trade politics. We show that when trade issues remain in the purview of Congress, party control of Congress, not just the form of government, determines conditions under which trade policy becomes a partisan issue.

Last, an important void in comparative studies of agricultural protection is the lack of theory that explains dynamics in agricultural protection within a country. The knowledge on country's factor endowment, agricultural production technology, national income, and political institutions, all of which prove to be important in understanding the cross-national variation in the protection of agriculture, does not necessarily enable us to predict the politics of agricultural protection in a country in the short or medium term.

${ }^{22}$ During the 2008 presidential campaign, McCain said, "If I [McCain] am elected president, I [McCain] will seek an end to all agricultural tariffs, and to all farm subsidies that are not based on clear need. I [McCain] will veto any bill containing special-interest favors and corporate welfare in any form" (Reuters 2008). In a statement on the passage of the farm bill in the Senate, "I [Obama] applaud the Senate's passage today of the farm bill, which will provide America's hard-working farmers and ranchers with more support and more predictability" (USA Today 2008). 


\section{REFERENCES}

Anderson, Kym and Yujiro Hayami. 1986. The Political Economy of Agricultural Protection. Sydney: Allen and Unwin.

Becker, Georey S. 2002. "Farm Commodity Legislation: Chronology, 1933-2002." CRS Report for Congress.

Browne, William P. 1995. Cultivating Congress: Constituents, Issues, and Interests in Agricultural Policymaking. Lawrence, KS: University Press of Kansas.

Bureau of Economic Analysis, Regional Economic Accounts. Accessed at https://www.bea.gov/regional/.

Chite, Ralph M. 2008. "Farm Bill Budget and Costs: 2002 vs. 2007." CRS Report for Congress.

Cox, Gary and Matthew McCubbins. 1993. Legislative Leviathan: Party Government in the House. Berkeley, CA: University of California Press.

Daugbjerg, Carsten and Alan Swinbank. 2012. "Special issue on Policy Analysis and the 'New' Politics of Food and Agriculture." Policy and Society 31(4), 259-270.

Davis, Christina L. 2003. Food Fights over Free Trade. Princeton, NJ: Princeton University Press.

Deering, Christopher J. and Steven S. Smith. 1997. Committees in Congress. Washington, DC: CQ Press.

Department of Agriculture. 2013. "A Short History of SNAP." November 20. Accessed at www.fns.usda.gov/snap/short-history-snap (April 22, 2014).

Environmental Working Group. 2013. "More Than 630 Editorials Call for Farm Bill Reform.” June 19. Accessed at www.ewg.org/release/more-630-editorials-call-farm-bill-reform (April 22, 2014).

Ferejohn, John. 1986. "Logrolling in an Institutional Context: A Case Study of Food Stamp Legislation.” In Leroy N. Rieselbach, Gerald C. Wright and Lawrence C. Dobb eds., Congress and Policy Change. New York: Agothon Press.

Gardner, Bruce L. 1987. “Causes of U.S. Farm Commodity Programs.” Journal of Political Economy 95(2), 290-310.

Gawande, Kishore and Bernard Hoekman. 2006. "Lobbying and Agricultural Trade Policy in the United States." International Organization 60(3), 527-561.

Gelman, Andrew and Jennifer Hill. 2007. Data Analysis Using Regression and Multi- level/Hierarchical Models. New York: Cambridge University Press.

Greene, William H. 2000. Econometric Analysis. $4^{\text {th }}$ ed. Upper Saddle River, NJ: 
Prentice Hall.

Gundersen, Craig, Michael Leblanc and Betsey Kuhn. 1999. "The Changing Food Assistance Landscape: The Food Stamp Program in a Post-Welfare Reform Environment." Paper provided by United States Department of Agriculture, Agricultural Economics Reports.

Hansen, John Mark. 1991. Gaining Access: Congress and the Farm Lobby, 19191981. Chicago: University of Chicago Press.

Hurwitz, Mark S., Roger J. Moiles and David W. Rohde. 2001. "Distributive and Partisan Issues in Agriculture Policy in the 104th House." American Political Science Review 95(4), 911-922.

Jacobson, Gary C. 2010. Divider, Not a Uniter: George W. Bush and the American People. 2nd ed. New York: Longman.

Kiewiet, D. Roderick and Mathew D. McCubbins. 1988. "Presidential Influence on Congressional Appropriations Decisions." American Journal of Political Science 32(3), 713-736.

King, Ronald F. 1999. "Welfare Reform: Block Grants, Expenditure Caps, and the Paradox of the Food Stamp Program." Political Science Quarterly 114(3), 359-385.

. 2000. Budgeting Entitlements: The Politics of Food Stamps. Washington, DC: Georgetown University Press.

Krehbiel, Keith. 1991. Information and Legislative Organization. Ann Arbor, MI: University of Michigan Press. . 1996. "Institutional and Partisan Sources of Gridlock: A Theory of Divided and Unified Government." Journal of Theoretical Politics 8(1), 7-40.

Lowi, Theodore J. 1964. "American Business, Public Policy, Case-Studies, and Political Theory." World Politics 16(4), 677-715.

MABLE/Geocorr. 1997. (Version 2)-Help Page (February 22). Accessed at http://mcdc2.missouri.edu/websas/geocorr9o_htmls/geocorr.help.ht $\mathrm{ml}$ (April 22, 2014).

McCarty, Nolan, Keith T. Poole and Howard Rosenthal. 2006. Polarized America: The Dance of Ideology and Unequal Riches. Cambridge, MA: MIT Press.

McGillivray, Fiona. 1997. "Party Discipline as a Determinant of the Endogenous Formation of Taris." American Journal of Political Science 41(2), 584-607.

McQuillan, Lawrence J. and Lydia D. Ortega. 1992. "Conference Committee Participation and Party Loyalty.” Public Choice 74(4), 485-494.

Miller, Gary and Norman Schofield. 2003. "Activists and Partisan Realignment in the United States." American Political Science Review 97(2), 245-260. . 2008. "The Transformation of the Republican and Democratic Party Coalitions in the U.S." Perspectives on Politics 6(3), 433-450. 
Nadeau, Richard and Harold W. Stanley. 1993. "Class Polarization in Partisanship among Native Southern Whites, 1952-90.” American Journal of Political Science 37(3), 900-919.

Nelson, Garrison. n.d. "Congressional Committee Assignments, 1947-1994." Accessed at http://web.mit.edu/17.251/www/data_page.html (April 22, 2014).

New York Times. 1998. "In Slap at G.O.P. Leadership, House Stops Move to Deny Food Stamps to Immigrants" (May 23). . 2001. "As House Prepares Farm Bill, Questions of Who Needs Help, and How Much" (September 9).

OECD (Organization for Economic Cooperation and Development). 2007. OECD-FAO Agricultural Outlook 2007-2016. OECD.

Park, Jong Heeand Nathan Jensen. 2007. "Electoral Competition and Agricultural Support in OECD Countries." American Journal of Political Science 51(2), 314-329.

Reuters. 2008. "McCain Vows to Fight U.S. Farm Subsidies, Tariffs" (May 19). Accessed at http://in.reuters.com/article/2008/05/19/usa-politicsmccain-agriculture-idINN1949916020080519.

Shepsle, Kenneth A. and Barry R. Weingast. 1987. "The Institutional Foundations of Committee Power.” American Political Science Review 81(1), 85-104.

Sinclair, Barbara. 1983. Majority Leadership in the U.S. House. Baltimore, MD: Johns Hopkins University Press. . 1995. Legislators, Leaders, and Lawmaking. Baltimore, MD: Johns Hopkins University Press.

Smith, Steven S. 1988. "An Essay on Sequence, Position, Goals, and Committee Power" Legislative Studies Quarterly 13(2), 151-176.

Stewart, Charles and Jonathan Woon. 2009. "Congressional Committee Assignments Data 1993-2005: Standing and Permanent Committees of the 103rd to 109th Congresses." January 3. Accessed at http://web.mit.edu/ 17.251/www/data_page.html (April 22, 2014).

Sundquist, James L. 1983. Dynamics of the Party System: Alignment and Realignment of Political Parties in the United States. Washington, DC: The Brookings Institution.

Thies, Cameron G. and Schuyler Porche. 2007. "The Political Economy of Agricultural Protection.” Journal of Politics 69, 116-127.

Thies, Michael F. 1998. "When Will Pork Leave the Farm? Institutional Bias in Japan and the United States." Legislative Studies Quarterly 23(4), 467-492.

USA Today. 2008. "Bill Includes Billions in Farm Subsidies" (May 15). Accessed at http://usatoday30.usatoday.com/news/washington/2008-05-15- 
farmbill_N.htm.

Vander Wielen, Ryan J. 2010. "The Influence of Conference Committees on Policy Out- comes." Legislative Studies Quarterly 35(4), 487-518.

Wattenberg, Martin P. 1991. "The Building of a Republican Regional Base in the South the Elephant Crosses the Mason-Dixon Line.” Public Opinion Quarterly 55(3), 424-431.

Weaver, R. Kent. 1996. "Deficits and Devolution in the 104th Congress." Journal of Federalism 26(3), 45-85.

Wiseman, Alan E. and John R. Wright. 2008. "The Legislative Median and Partisan Policy.” Journal of Theoretical Politics 20(1), 5-29.

[Received J anuary 24, 2014; Revised April 28, 2014; Accepted J une 8, 2014] 


\section{APPENDIX 1. Data Coding}

Majority: 1 if a House representative is a majority party member, and o otherwise.

Unified Congress: 1 if a political party holds majority in both chambers, and o otherwise.

Appropriations: 1 if a House representative is a member of the House Appropriations Committee, and o otherwise.

Agriculture: 1 if a House representative is a member of the House Agriculture Committee, and o otherwise.

Democratic Government: 1 if the Democratic party holds majority in both chambers and the president is a Democrat, and o otherwise.

Republican Congress: 1 if the Republican party holds majority in both chambers, and o otherwise.

\section{APPENDIX 2. Dynamic Equilibria of the Game}

In this section, we explain the dynamic equilibria of the farm bill game briefly explained in the article. We benchmark the formal proof of the game by Krehbiel (1996) to find the equilibria. Based on the analysis of party platforms on farm support programs, we assume that Democratic presidents prefer larger agricultural spending compared to Republican presidents. We also assume that the median legislator's ideal point moves toward the majority party median in the presence of unified party control of both houses following Wiseman and Wright (2008). Under divided party control of Congress, the median legislator is located at the center of the spectrum, representing the mid-point between the two median legislators in the House and in the Senate.

The location of the median legislator's ideal point changes depending on the partisan composition of two houses. The movement of the median legislator's ideal point also changes the locations of other pivotal players' positions. To denote these overall changes, we use the thick solid horizontal lines, which can be interpreted as relevant policy spaces in each farm bill Congress. In the absence of the bicameral majority, the policy space is centered in the middle. This is the cases in 1981, 1985, and 2002. When the Democratic Party has the majority in both houses, 1973, 1977, and 1990, the policy space moves to the left. The Republican control of two houses in 1996 moved the policy space to the right. We assume that the status quo in the 1973 farm bill was located at the center. Also, we assume that 
a Democratic president prefers more spending on farm bills while a Republican president prefers less spending on farm bills.

Whenever the status quo is located between $\mathrm{f}$ and $\mathrm{v}$, it is hard to change the status quo as these two pivotal players can block any policy changes which make them worse off. For example, in the 1973 farm bill, Democratic Congress had the bicameral majority.

The median legislator is located slightly left of the center. The president was Republican. The filibuster pivot is located left of the median legislator, and the veto pivot is located slightly right of the status quo. Thus, $f-M-S Q-v-P$ in the first line of Figure 3 results.

In this arrangement of the preferences, any proposal by $\mathrm{M}$ to change the status quo will be blocked either by $\mathrm{f}$ or $\mathrm{v}$. Thus, the status quo rules. In the 1977 farm bill, the status quo inherited from the 1973 farm bill is located right of all the pivotal players' ideal points. However, the status quo is closer to the filibuster pivot than to the median legislator: $p-v-M-f-S Q$ Thus, the median legislator has to make a proposal that makes $f$ indifferent, and the status quo is moved to $f$. For the rest of the farm bill Congresses, the status quo established in the 1977 farm bill is located between $f$ and $v$, and hence no major change in the farm bill budget is feasible.

Figure 3. Dynamic Analysis of the Agricultural Spending Across Seven Farm Bill Congresses

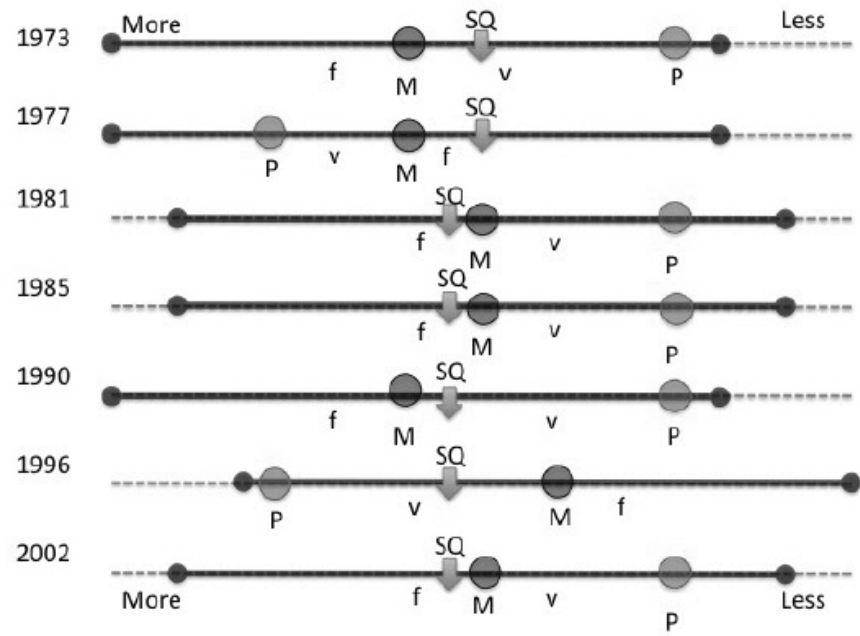

Note: $S Q$ indicates the location of the status quo, $f$ denotes the location of the filibuster pivot, $v$ denotes the location of the veto pivot, $P$ denotes the location of the president, and $M$ denotes the location of the median legislator. Locations of the median legislator are assumed to move to the left (right) when the Democratic (Republican) party has the majority in both houses. A Democratic president is assumed to prefer larger agricultural spending than a Republican president. 


\section{APPENDIX 3. Roll Call Data Analysis}

It is difficult to test our hypotheses using the roll call voting results because of the observational equivalence in the voting results among three cases: unified Democratic government, unified Democratic Congress, and divided Congress. In those three cases, the farm-food coalitions in both parties and Democrats are likely to vote for the farm bill either based on their district interests or based on partisan interests. The only identifiable case is unified Republican Congress in which the Republican members outside the food-farm coalition should vote for the farm bill according to our hypothesis.

We can illustrate the observational equivalence using a simple example of a hypothetical Congress with four voting blocs: $d, D, R, r . d$ and D consist of Democrats and $R$ and $r$ consist of Republicans. $D$ and $R$ are legislators within the food-farm coalition and $d$ and $r$ are party members without strong interests in the farm bill.

The first case is Democratic government; that is, $d+D>R+r$ in both houses. Here, a simple majority of Democrats $(d+D)$ would be sufficient to pass the farm bill because of a co-partisan president unified Democratic government increases both farm payments and the food stamp program. Republicans whose districts have strong interests in the passage of the farm bill are also likely to vote for the farm bill to secure their positions in elections. Even though Republicans in $R$ are likely to support the highly Democratic farm bill due to their district interests, Democrats do not need to consider their interests. We do not discuss a unified Republican government for two obvious reasons. First, the prediction would simply be the opposite of a unified Democratic government, with a final voting coalition solely consists of Republicans, $R+r$. Second, there are no cases of a unified Republican government in farm bill legislations since 1973.

The second case is a unified Democratic Congress with a Republican president. A simple Democratic majority would not be sufficient to pass the bill against the president's veto threat on the grounds that the bill is tilted too heavily to Democratic interests or costs too much. The presence of a Republican president serves as a strong budget constraint in the farm bill. Thus, Democrats need to compromise by including the cheapest $R \mathrm{~s}$ in the final package. Although this maneuver would create a veto-proof coalition, Democrats would not be able to increase the total size of the bill as they might do under unified Democratic government. The likely final voting coalition consists of $d+D+R$, which is observationally equivalent to the one under unified Democratic government. The important difference is that this farm bill authorized by a unified Democratic Congress reflects a trade-off under the budget constraint and a compromise with 
Republican members from the farm coalition.

Table 6 tabulates the vote choices by party and by farm bill Congresses. The $x^{2}$ test shows that the associations between members' party affiliations and vote choices are statistically significant at the 95\% confidence level in five farm bills reauthorized under unified Congresses (1973, 1977, 1990, 1996, and 2008). Although these results are generally in support of our theory, the results should be taken with care as the statistical significance does not tell us much about why party affiliations became significant in vote choices for the final passage of farm bills enacted under unified Congresses. In other words, we do not know whether Democrats voted for a farm bill because of their district interests or their party affiliations.

One interesting finding from the roll call data analysis is that the voting results for the 1996 farm bill are highly different from the voting results from other farm bills. In the 1996 farm bill, 93\% of Republicans voted for the final passage of the farm bill while there are only $60 \%$ of Democrats who voted for the final passage of the farm bill.

In other farm bills, the percentage (and raw numbers) of Republicans who supported the final passage of the farm bill was always smaller than that of Democrats. Compare the results with weak support for farm bills by Republican party members when the Congress is controlled by Democrats. The average proportion of Republican legislators who voted for the farm bill between divided Congresses (1981, 1985, 2002) and unified Democratic Congresses (1973, 1977, $1990,2008)$ are 0.5407 and 0.7181 , respectively. The difference is statistically significant. However, the difference in the average proportion of Democratic legislators who voted for the farm bill between divided Congresses $(1981,1985,2002)$ and unified Democratic Congresses (1973, 1977, 1990, 2008) are not statistically significant; 0.7150 and 0.7787 , respectively. This result indicates that changes in voting patterns in final passage votes of farm bills were largely driven by fluctuations in the support for farm bills among Republicans.

The third case is a unified Republican Congress with a Democratic president; $d$ $+D<R+r$. The Republican Congress would like to decrease farm payments and food stamps, but the Democratic president can veto this change from the status quo. To secure a veto-proof majority, Republicans must include some in $D$. In other words, despite its wishes, a Republican Congress cannot simultaneously decrease both the farm payments and food stamp benefits, and is forced to compromise in order to ensure a veto-proof coalition. The final coalition consists of $D+R+r$.

The last case is a divided Congress; $d+D>R+r$ in one house and $d+D<R+$ $r$ in the other house. Regardless of the president's partisanship, neither 
Democrats nor Republicans can structure the farm bill in their favor. Because each house (and hence each party) has veto power over the other's proposal, the status quo continues. $D+R$ will support the farm bill and $d$ is likely to vote for it on ideological grounds. Thus, the final voting coalition consists of $d+D+R$ without much substantive change to the farm bill.

Table 6. Party Affiliations and Vote Choices in the Final Passage of Farm Bills

\begin{tabular}{|c|c|c|c|c|c|c|c|c|}
\hline & 1973 & 1977 & 1981 & 1985 & 1990 & 1996 & 2002 & 2008 \\
\hline Unified Congress & Yes & Yes & No & No & Yes & Yes & No & Yes \\
\hline Vote Choice & $\begin{array}{ll}\mathrm{Y} & \mathrm{N} \\
\end{array}$ & $\begin{array}{ll}\mathrm{Y} & \mathrm{N} \\
\end{array}$ & $\mathrm{Y} \quad \mathrm{N}$ & $\begin{array}{ll}\mathrm{Y} & \mathrm{N} \\
\end{array}$ & $\begin{array}{ll}\mathrm{Y} & \mathrm{N} \\
\end{array}$ & $\begin{array}{ll}\mathrm{Y} & \mathrm{N} \\
\end{array}$ & $\begin{array}{ll}\mathrm{Y} & \mathrm{N} \\
\end{array}$ & $\begin{array}{ll}\mathrm{Y} & \mathrm{N} \\
\end{array}$ \\
\hline Democrat & $\begin{array}{lr}139 & 86 \\
(61.78 \%)\end{array}$ & $\begin{array}{lr}219 & 69 \\
(76.04 \%)\end{array}$ & $\begin{array}{lr}152 & 69 \\
(68.78 \%)\end{array}$ & $\begin{array}{lr}194 & 49 \\
(79.84 \%)\end{array}$ & $\begin{array}{lr}197 & 50 \\
(79.76 \%)\end{array}$ & $\begin{array}{lr}106 & 72 \\
(59.55 \%)\end{array}$ & $\begin{array}{lr}141 & 73 \\
(65.89 \%)\end{array}$ & $\begin{array}{lr}216 & 14 \\
(93.91 \%)\end{array}$ \\
\hline Republican & $\begin{array}{cr}86 & 95 \\
(47.51 \%)\end{array}$ & $\begin{array}{rr}64 & 71 \\
(47.40 \%)\end{array}$ & $\begin{array}{l}141 \quad 47 \\
(75.00 \%)\end{array}$ & $\begin{array}{lr}131 & 47 \\
(73.60 \%)\end{array}$ & $\begin{array}{lr}118 & 51 \\
(69.82 \%)\end{array}$ & $\begin{array}{lr}211 & 17 \\
(92.54 \%)\end{array}$ & $\begin{array}{lr}137 & 68 \\
(66.83 \%)\end{array}$ & $\begin{array}{lr}100 & 94 \\
(51.55 \%)\end{array}$ \\
\hline$\chi^{2}$ & 8.26 & 34.03 & 1.93 & 2.27 & 5.38 & 63.57 & 0.04 & 99.50 \\
\hline$p$-value & 0.00 & 0.00 & 0.16 & 0.13 & 0.02 & 0.00 & 0.83 & 0.00 \\
\hline
\end{tabular}

Note: $\mathrm{Y}$ and $\mathrm{N}$ denote the number of party members who vote for and against final passage of farm bills, respectively. Numbers in the parentheses are the percentage of party members who voted for the farm bills. 